\title{
Reassessment of NRC's Dollar Per Person-Rem Conversion Factor Policy
}

Manuscript Completed: December 1995

Date Published: December 1995

Division of Regulatory Applications Office of Nuclear Regulatory Research U.S. Nuclear Regulatory Commission

Washington, DC 20555-0001

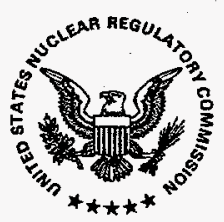




\section{DISCLAMMER}

Portions of this document may be illegible in electronic image products. Images are produced from the best available original document. 


\begin{abstract}
The Nuclear Regulatory Commission has completed a review and analysis of its dollar per person-rem conversion factor policy. As a result of this review, the NRC has decided to adopt a $\$ 2000$ per person-rem conversion factor, subject it to present worth considerations, and limit its scope solely to health effects. This is in contrast

an undiscounted $\$ 1000$ per person-rem

conversion factor that served as a surrogate for all offsite consequences (health and offsite property). This policy shift has been incorporated in "Regulatory Analysis Guidelines of the U.S. Nuclear Regulatory Commission," NUREG/BR-0058, Revision 2, November 1995.
\end{abstract} to the previous policy and staff practice of using 



\section{CONTENTS}

Page

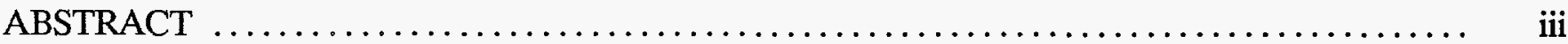

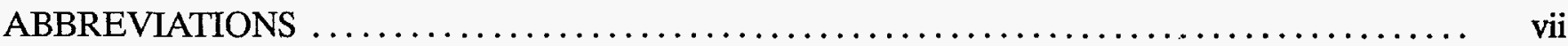

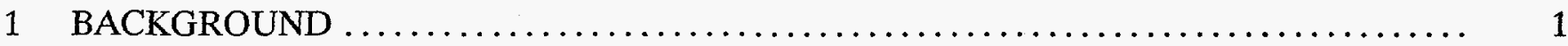

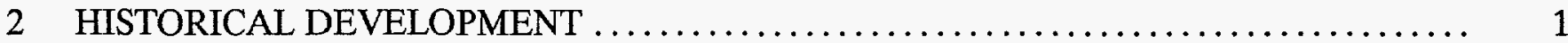

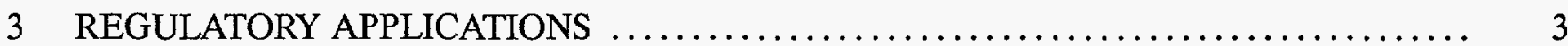

3.1 Routine Emissions from Nuclear Power Plants ........................... 4

3.2 Accidental Releases ............................................. 4

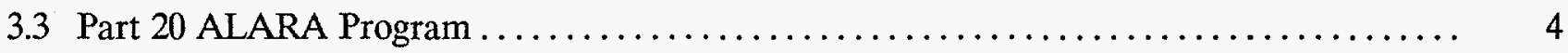

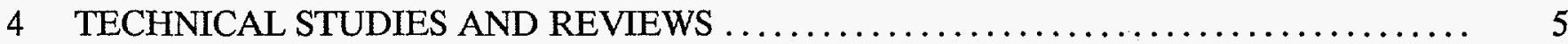

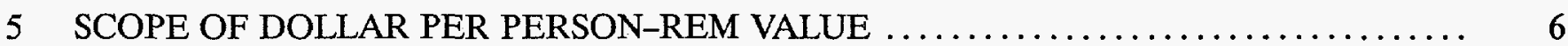

6 APPROACHES TO VALUING THE HEALTH DETRIMENT $\ldots \ldots \ldots \ldots \ldots \ldots \ldots \ldots . \ldots \ldots$

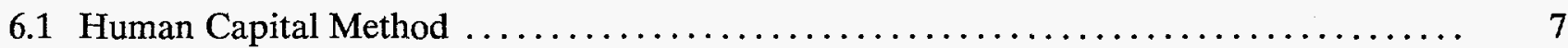

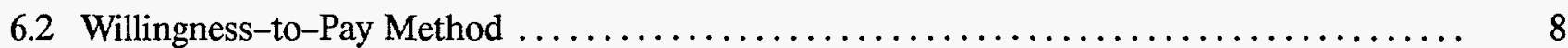

6.3 Values Implied by Government Agency Expenditures ...................... 10

6.4 Values Implied by Regulatory Requirements Imposed by Government Agencies ....... 10

6.5 Values Based on Radiation Protection Activities in Other Countries ............... 10

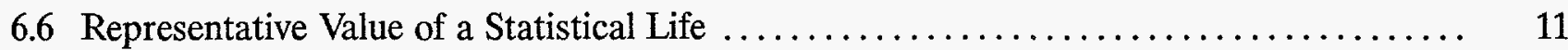

7 RISK COEFFICIENTS FOR STOCHASTIC HEALTH EFFECTS . . . . . . . . . . . . . . . . 11

8 DOLLAR PER PERSON-REM CONVERSION FACTOR ....................... 12

$9 \quad$ IMPLICATIONS OF REVISED CONVERSION FACTOR POLICY $\ldots \ldots \ldots \ldots \ldots \ldots \ldots \ldots \ldots$

10 PROCESS TO INCORPORATE THE REVISED DOLLAR PER PERSON-REM VALUE AS NRC POLICY 



\section{ABBREVIATIONS}

\begin{tabular}{|c|c|c|c|}
\hline $\begin{array}{l}\text { ALARA } \\
\text { BETR V }\end{array}$ & as low as reasonably achievable & NCRP & $\begin{array}{l}\text { National Council on Radiation } \\
\text { Protection }\end{array}$ \\
\hline BEIR V & $\begin{array}{l}\text { Committee on the Biological } \\
\text { Effects of Ionizing Radiation }\end{array}$ & NEPA & National Environmental Policy Act \\
\hline $\mathrm{BNL}$ & Brookhaven National Laboratory & $\mathrm{NRC}$ & Nuclear Regulatory Commission \\
\hline CPSC & Consumer Product Safety & OMB & Office of Management and Budget \\
\hline DOT & $\begin{array}{l}\text { Commission } \\
\text { Department of Transportation }\end{array}$ & OSHA & $\begin{array}{l}\text { Occupational Safety and Health } \\
\text { Administration }\end{array}$ \\
\hline EPA & Environmental Protection Agency & PNL & Pacific Northwest Laboratory \\
\hline GDP & gross domestic product & PRA & probablistic risk assessment \\
\hline GESSAR & $\begin{array}{l}\text { General Electric Standard Safety } \\
\text { Analysis Report }\end{array}$ & SAMDA & $\begin{array}{l}\text { Severe Accident Mitigation Design } \\
\text { Alternative }\end{array}$ \\
\hline GI & generic issue & TMI & Three Mile Island \\
\hline HECOM & Health Effects Cost Model & UNSCEAR & United Nations Scientific \\
\hline ICRP & $\begin{array}{l}\text { International Commission on } \\
\text { Radiation Protection }\end{array}$ & & $\begin{array}{l}\text { Committee on the Effects of } \\
\text { Atomic Radiation }\end{array}$ \\
\hline \multirow[t]{2}{*}{ MACCS } & \multirow{2}{*}{$\begin{array}{l}\text { MELCOR Accident Consequence } \\
\text { Code System }\end{array}$} & USI & unresolved safety issues \\
\hline & & WTP & Willingness-to-Pay \\
\hline
\end{tabular}




\section{BACKGROUND}

For approximately the last two decades, the U.S. Nuclear Regulatory Commission (NRC) and its predecessor agency, the Atomic Energy Commission, have used a conversion factor of $\$ 1000$ per person-rem ${ }^{1}$ as the monetary valuation of the consequences associated with radiological exposure. That is, an increase or decrease in person-rem is valued at $\$ 1000$ per person-rem in order to allow a quantitative comparison of the values and impacts associated with a proposed regulatory decision.

This value has been used as a reference point in NRC regulatory analyses ${ }^{2}$ including those involving (a) routine emissions, (b) accidental releases, and (c) 10 CFR Part 20 as low as reasonably achievable (ALARA) programs.

The NRC prepares regulatory analyses for proposed actions imposing requirements on licensees. The analyses include an examination of the values and impacts associated with alternative approaches to meeting the particular regulatory objectives. The conclusions and recommendations included in a regulatory analysis are neither final nor binding, but rather are intended to enhance the soundness of decisions made by NRC managers and the Commission. Regulatory actions needed to ensure adequate protection of the health and safety of the public [see section 182(a) of the Atomic Energy Act and 10 CFR 50.109(a)(4)(ii)] from the operation of production and utilization facilities do not require a regulatory analysis. Thus the $\$ 1000$ per person-rem conversion factor does not apply to these actions, except in assessing possible alternative approaches to achieve the necessary level of adequate protection.

Over the years, the NRC has become increasingly aware of alternative estimates and methodological

\footnotetext{
${ }^{1}$ In order to be consistent with the Commission's policy on metrication, the conversion factor should be expressed in dollars per person-centisievert with the value in English units following parenthetically. Note that a sievert is equal to 100 rems.

Therefore, for example, $\$ 1000$ per person-rem is equal to $\$ 1000$ per person cSv. However, for purposes of continuity and to facilitate review, dollars per person-rem shall be the unit used throughout this report.

${ }^{2}$ Guidance for the preparation of NRC's regulatory analyses is in Regulatory Analysis Guidelines of the U.S. Nuclear Regulatory Commission, NUREG/BR-0058, Rev. 2.
}

approaches for arriving at a conversion factor. In addition, questions have surfaced on the continued validity of the $\$ 1000$ per person-rem conversion factor because basic parameters such as the value of the dollar and risk factors (e.g., latent cancer fatality estimates per person-rem) have changed considerably over this period. Such factors have potentially significant effects on the appropriateness of the $\$ 1000$ per person-rem conversion factor. In the NRC's view, a thorough reassessment of the dollar per person-rem value and its application in NRC regulatory decisionmaking is needed.

The NRC's revision is based on a relatively simple and straightforward logic in which the new dollar per person-rem conversion factor attempts to capture the dollar value of the health detriment resulting from radiation exposure. As such, the proposed formulation considers the dollar value of the health detriment, and a risk factor that establishes the nominal probability for stochostic health effects attributable to radiological exposure. The latter term takes into account fatal and non-fatal cancers, and hereditary effects. It needs to be emphasized that the resulting dollar per person-rem conversion factor is not applicable to deterministic health effects, including early fatalities, which could result from very high doses to particular individuals. In this way, the conversion factor is compatible with the Commission's Safety Goal Policy wherein the Commission made clear that no death will ever be "acceptable" in the sense that the Commission would regard it as a routine or permissible event.

\section{HISTORICAL DEVELOPMENT}

The issue of assigning a monetary value to radiation dose in regulatory decisionmaking arose in 1974 during the hearing for a rulemaking addressing routine emissions from nuclear power reactors (the rule subsequently issued appears at 10 CFR Part 50, Appendix I). ${ }^{3}$ In adopting design criteria for limiting routine emissions from power plants, the Commission argued for a cost-benefit test. The Commission felt that "such a cost-benefit analysis requires that both the costs

\footnotetext{
${ }^{3}$ U.S. Nuclear Regulatory Commission, Numerical Guides for Design Objectives and Limiting Conditions for Operating to Meet the Criterion "As Low as is Reasonably Achievable" for Radioactive Material in Light-Water-Cooled Nuclear Power Reactor Effluents, Opinion of the Commission, April 30, 1975.
} 
and the benefits from the reduction in dose levels to the population be expressed in commensurate units, and it seems sound that these units be units of money. Accordingly, to accomplish the cost-benefit balancing, it is necessary that the worth of a decrease of a person-rem be assigned monetary values." 4

The Commission stated that "the record, in our view, does not provide an adequate basis to choose a specific dollar value for the worth of decreasing the population dose by a man-rem." Published studies at that time that were mentioned in the record of the rulemaking, gave values ranging from $\$ 10$ to $\$ 980$ per person-rem. The Commission concluded that "there is no consensus in this record or otherwise regarding the proper value for the worth of a manrem," and that "we also recognize that selection of such values is difficult since it involves, in addition to actuarial considerations that are commonly reduced to financial terms, aesthetic, moral, and human values that are difficult to quantify." 5 The final outcome was a Commission decision to adopt as an interim measure, the value of $\$ 1000$ per person-rem for cost-benefit evaluations. ${ }^{6}$

Two Executive Orders issued during the Ford administration (E.O. 11821 and E.O. 11949) encouraged Federal agencies to perform value-impact type evaluations of proposed regulatory requirements to demonstrate adequate justification for new requirements. The NRC became committed to this type of evaluation, and issued Value-Impact Guidelines in December 1977 (SECY-77-388A). This document referred to the techniques and detailed consequence analyses used in the Reactor Safety Study, WASH-1400, and recommended that the person-rem averted from proposed changes be multiplied..."by $\$ 1000$ per man-rem (or other agreed upon value)," in order to place the benefit (value) in the same units as cost (impact).

In 1977, Congress added Section 210 to the Energy Reorganization Act of 1974, directing the NRC to develop a plan for the identification and analysis of unresolved safety issues (USI) relating to nuclear reactors. In response, the NRC developed a program for the identification,

${ }^{4}$ Federal Register, May 5, 1975 (40 FR 19439), page 19439.

5Ibid.

${ }^{6}$ Ibid. prioritization, and resolution of USI's and generic issues (GI). Guidance relating to the assignment of priorities was issued in 1982, with the publication of "A Prioritization of Generic Safety Issues," NUREG-0933. The guidance included the use of the $\$ 1000$ per person-rem value in setting the priority of USIs and GIs. Issues identified as high priority were then subject to resolution via a more detailed value-impact analysis that also utilized the $\$ 1000$ per person-rem value. In both these contexts, the $\$ 1000$ per person-rem value has been used as a figure of merit and as one factor in the respective assessments.

In January and December 1983, the NRC published NUREG/BR-0058, "Regulatory Analysis Guidelines of the U.S. Nuclear Regulatory Commission" (Guidelines), and NUREG/CR-3568, "A Handbook for Value-Impact Assessment" ("1983 Handbook"), respectively. These documents were issued to formalize NRC's policies and procedures for analyzing the values and impacts of proposed regulatory requirements. The $\$ 1000$ per person-rem figure was not mentioned in the 1983 Guidelines or in Revision 1 to the Guidelines issued in May 1984, but the accompanying 1983 Handbook recommended that the analyst use a range of values, one of which should be $\$ 1000$ per person-rem. ${ }^{7}$ Since the 1983 Handbook provides the implementation guidance for performing NRC regulatory analyses, it became standard practice of the NRC staff to apply this guidance whenever a quantitative regulatory analysis or value-impact analysis was performed.

The NRC requires a regulatory analysis for a broad range of regulatory actions. In general, all mechanisms used by the staff to establish or communicate generic requirements, requests, or staff positions, that would affect a change in the use of resources by its licensees will include an accompanying regulatory analysis. These mechanisms include rules, bulletins, generic letters, regulatory guides, orders, standard review plans, branch technical positions, and standard technical specifications. Thus, staff guidance on value-impact and regulatory analyses has provided the NRC with a mechanism to consider $\$ 1000$ per person-rem as a figure of merit in most

\footnotetext{
${ }^{7}$ S. W. Heaberlin, et al., "A Handbook for Value-Impact Assessment," NUREG/CR-3568. Section 3.2.2., 1983.
} 
regulatory decisions affecting power reactor as well as nonpower-reactor licensees. In practice, however, a number of regulatory analyses did not quantify the person-rem averted and thus did not use a dollar per person-rem value.

In 1983, the NRC issued an interim Policy Statement on Safety Goals for the Operation of Nuclear Power Plants for use during a 2-year trial period. ${ }^{8}$ In this statement, the Commission adopted qualitative and quantitative design goals for limiting individual and societal mortality risks from severe accidents. Also in this Statement, the Commission stated that the benefit of an incremental reduction of societal mortality risks should be compared with the associated costs on the basis of $\$ 1000$ per person-rem averted as one consideration in decisions on safety improvements. The value proposed was in 1983 dollars and was to be modified to reflect general inflation in the future. At the end of the 2-year interim period, a number of comments were received on this value. Widely different values were suggested ranging from about $\$ 100$ per person-rem to values in excess of $\$ 1000$ per person-rem. Respondents who believed the $\$ 1000$ value was too low did not provide another number, but merely indicated that the value should be raised. Discussion of $\$ 1000$ per person-rem, and any proposed use, were deleted in the Final Policy Statement on Safety Goals when published in August 1986 (51 FR 30028), following completion of the 2-year trial period. ${ }^{9}$

In 1985 , the NRC staff revisited the $\$ 1000$ per person-rem valuation and its use in regulatory analyses of nuclear power plant improvements designed to enhance safety. Although the monetary value of averted person-rem of radiation exposure up to that time referred only to averted health effects, (for example, averted latent cancer fatalities), the use of $\$ 1000$ per person-rem was evaluated and subsequently defined at that time as a surrogate for all averted offsite losses, health as well as property. The basis for this determination is in an October 23, 1985, memorandum from NRC's Executive Director for

${ }^{8}$ U.S. Nuclear Regulatory Commission, "Safety Goals for Nuclear Power Plant Operation," NUREG-0880, Rev. 1, May 1983.

${ }^{9}$ The $\$ 1000$ per person-rem value was mentioned in the separate views of Commissioner Bernthal (51 FR 30033).
Operations to the Commissioners. ${ }^{10}$ This interpretation was subsequently adopted in all NRC regulatory analyses and value-impact analyses in which offsite radioactive releases were subject to monetary valuation.

In February 1982, as part of the Three Mile Island (TMI) Action Plan, the Commission promulgated 10 CFR 50.34(f)(1)(i) that required certain nuclear power plant license applicants to prepare plant-specific probabilistic risk assessments (PRAs) to identify possible design alternatives for nuclear power plants. As a result of this rule, value-impact analyses were prepared in 1985 for the GESSAR (General Electric Standard Safety Analysis Report) design. Eighty design-specific enhancements were analyzed with $\$ 1000$ per person-rem used as the screening criterion. PRAs are now used for existing operating nuclear power plants (as a result of NRC Generic Letter 88-20) and for future reactor designs.

In February 1989, the U.S. Court of Appeals directed the NRC to consider Severe Accident Mitigation Design Alternatives (SAMDA) as part of the NRC's environmental review process under the National Environmental Policy Act (NEPA) before granting a full power license to owners of nuclear power plants. ${ }^{11}$ The staff subsequently performed SAMDA analyses for the Limerick and Comanche Peak nuclear power plants. A SAMDA analysis was also prepared for the "Draft Generic Environmental Impact Statement for License Renewal of Nuclear Plants"

(NUREG-1437). In all these cases, the staff used the $\$ 1000$ per person-rem value as a screen to compare values and impacts. If designs were within an order of magnitude of being justified, they were analyzed further. No design changes were deemed necessary as a result of these SAMDA analyses.

\section{REGULATORY APPLICATIONS}

The $\$ 1000$ per person-rem conversion factor has been applied by the NRC in a variety of regulatory applications including the evaluation of (1) routine emissions from nuclear power plants,

\footnotetext{
${ }^{10}$ Memorandum, W. J. Dircks to Commission, "Basis for Quantifying Off-Site Property Losses," October 23, 1985.

${ }^{11}$ Limerick Ecology Action, Inc., v NRC, 869 F2d 719 (3d Cir. 1989).
} 
(2) accidental releases, and (3) radiation protection practices.

\subsection{Routine Emissions from Nuclear Power Plants}

The only place the $\$ 1000$ per person-rem value currently appears in the NRC's regulations is at 10 CFR Part 50, App. I (Sec. II)(D) in a paragraph relating to items to be included in a license applicant's radwaste system. Essentially, in designing the radwaste system, the licensee is not required to install additional effluent controls to reduce routine emissions below 3 millirem per year for water effluents and 5 millirem per year for airborne effluents if the cost of the resultant reduction in the exposure of the population within 50 miles is greater than $\$ 1000$ per total body person-rem or $\$ 1000$ per person-rem to the thyroid.

The $\$ 1000$ per person-rem criterion has served as a significant decision factor in NRC's radwaste design approval decisions for nuclear power plants. Guidance for performing the dose calculation and resulting dollar valuation is contained in the NRC's Regulatory Guides 1.109 and 1.110 , respectively. Procedurally, applicants for a nuclear plant license are to use $\$ 1000$ per person-rem in a cost-benefit analysis in order to justify their radwaste system design. The design is then subject to NRC approval and, depending upon the outcome of this review, possible revision. Essentially, all nuclear power plant operating licenses issued after 1975 have followed this procedure. Although NRC's regulations only speak to the use of the $\$ 1000$ per person-rem value in consideration of the radwaste system design, the staff believes that to some extent it has also influenced licensees' design considerations for radwaste storage facilities.

From a procedural standpoint, use of the $\$ 1000$ per person-rem value as a determinant in decisions involving radwaste systems has generally worked well. The decision criterion is well defined and effective staff procedures and licensee guidance are in place. However, from a practical perspective the $\$ 1000$ per person-rem value appears to have had relatively little effect on the radwaste system designs proposed by applicants and ultimately approved by the NRC. The reason is that system designs are relatively insensitive to an increase, within an order of magnitude, in the
$\$ 1000$ per person-rem criterion because of the relatively high cost of the design alternatives.

\subsection{Accidental Releases}

A frequent use of the $\$ 1000$ per person-rem valuation has involved NRC programs, reviews, and decisions in which accidental radiological releases are a consideration. This is because safety enhancement regulatory actions constitute a major NRC initiative, and accidental releases tend to be a dominant factor in these regulatory decisions.

From a procedural standpoint, the $\$ 1000$ conversion factor has also appeared to function as a useful guide in regulatory decisions in which accidental radiological releases are a consideration. As noted in Section 2 of this report, since 1985 , the $\$ 1000$ value has been interpreted by the NRC to include an allowance for all offsite property consequences of a nuclear power plant accident. This broader interpretation can be problematic for the reasons noted in Section 5 of this report.

\subsection{Part 20 ALARA Program}

The regulation 10 CFR Part 20 establishes standards for protection against radiation hazards arising out of activities under licenses issued by the NRC. A guiding principle for Part 20 (codified at 10 CFR 20.1101(b)) is for licensees to make every reasonable effort to maintain radiation exposures, and releases of radioactive materials, as low as is reasonably achievable. Part 20 applies to all NRC licensees (power reactor, nonpower reactor, fuel cycle facilities and radioactive source and materials licensees) and concerns the release of radioactive material and associated occupational and public dose incurred as a result of normal licensee activities.

ALARA is defined at 10 CFR 20.1003 as making every reasonable effort to maintain exposures to radiation as far below the Part 20 dose limits as is practical, taking into account the state of technology, the economics of improvements in relation to benefits to the health and safety of the public and occupational workers, other societal and socioeconomic considerations, and the utilization of nuclear energy in the public interest. Given this definition, it would appear that a dollar value per person-rem should play a pivotal role in cost-benefit tradeoffs used in establishing 
reasonableness under the Part 20 ALARA program. However, Part 20 itself does not address the use of the $\$ 1000$ per person-rem value although one regulatory guide ${ }^{12}$ (Regulatory Guide 8.37) suggests its use. In this regard, the NRC is aware that current industry practice, particularly in the power reactor arena, is to value an averted person-rem at a higher dollar value owing to manpower constraints and other labor cost considerations that are integral to the licensees' cost-benefit tradeoffs. Licensees are encouraged to continue to use such higher values for their own ALARA determinations.

Regulatory Guide 8.37 advises materials licensees that they should consider engineering options to achieve ALARA goals in the release of effluents and that modifications should be implemented unless an analysis indicates that a substantial reduction in collective dose would not result or the costs are considered unreasonable. One basis for reasonableness identified in this regulatory guide is a quantitative cost-benefit analysis which requires the use of a dollar value per unit dose averted. The Regulatory Guide indicates that $\$ 1000$ per person-rem is an acceptable value for this purpose.

In 1992 for an enhanced participatory rulemaking on radiological criteria for decommissioning, the NRC issued a notice (57 FR 58727) that identified issues to be discussed at forthcoming workshops on the proposed rulemaking. One subissue dealing with ALARA considerations asked: “... if a cost versus benefit analysis were used, what monetary value per averted collective dose (i.e., dollar/person-rem) should the Commission use as a basis for making the determination?" In responding to the subissue, only two commenters mentioned specific values. One recommended a value of $\$ 50,000$ per person-rem for general public dose reduction. Another stated that even in 1993 dollars, the $\$ 1000$ value is still higher than most assessments of the dollar value placed on health impacts based on real safety or medical policy decisions. Neither commenter provided a basis for their recommendations.

\footnotetext{
${ }^{12}$ Regulatory Guide 8.37, "ALARA Levels for Effluents from Materials Facilities," July 1993.
}

\section{TECHNICAL STUDIES AND REVIEWS}

As part of the NRC's overall reassessment effort of an appropriate dollar per person-rem conversion value, the Brookhaven National Laboratory (BNL) completed two studies for the $\mathrm{NRC}$ that addressed dollar per person-rem valuation. The first, entitled "Cost-Benefit Considerations in Regulatory Analysis," by V. Mubayi, et al., ${ }^{13}$ assessed the continued validity of the $\$ 1000$ per person-rem value. In addition, this study re-evaluated the dollar per person-rem value based on the more recent state of knowledge including reports issued by the International Commission on Radiation Protection (ICRP), the National Council on Radiation Protection and Measurements (NCRP), the United Nations Scientific Committee on the Effects of Atomic Radiation (UNSCEAR), and the Committee on the Biological Effects of Ionizing Radiation (BEIR V) of the National Research Council.

The second BNL study is entitled "Value of Public Health and Safety Actions and Radiation Dose Avoided," by John W. Baum. ${ }^{14}$ This report incorporates and builds upon the literature review contained in the Mubayi work with a focus on recent literature on the value of a statistical life that can serve as a representative measure of the dollar value of the health detriment. In addition, the report includes related values of dose avoided in radiation protection, and agencies and organizations in several countries were contacted by Baum to obtain information on the values being used or considered by them.

Baum's review identified a wide range of references and estimates that were categorized into 11 broad subject areas. The 11 subject areas and corresponding median values for the value of saving a statistical life are as follows:

- transportation safety, $\$ 0.26$ million

- health care actions, $\$ 0.37$ million

\footnotetext{
${ }^{13}$ V. Mubayi, G. Anandalingam, L. Neymotin, and V. Sailor, "Cost-Benefit Considerations in Regulatory Analysis,"

NUREG/CR-6349, Brookhaven National Laboratory, Upton, New York, October 1995.

${ }^{14}$ J. W. Baum, "Value of Public Health and Safety Actions and Radiation Dose Avoided," NUREG/CR-6212, Brookhaven National Laboratory, Upton, New York, May 1994.
} 
- consumer products safety, $\$ 0.49$ million

- values employed by U. S. Government agencies, \$1.5 million

- consumer choices, $\$ 2.2$ million

- wage/risk compensation, $\$ 2.5$ million

- willingness-to-pay surveys, $\$ 2.7$ million

- chemical carcinogen regulation, $\$ 2.9$ million

- risk reducing regulations, $\$ 6.1$ million

- occupational safety, $\$ 9$ million

- radiation related activities, $\$ 15$ million.

The median value of saving a statistical life for these 11 subject areas was $\$ 2.5$ million, while the mean was $\$ 3.9$ million.

Mubayi's report is somewhat more ambitious in that it also translates the value of a statistical life to a dollar per person-rem value. There is however a noticeable difference between Mubayi's conversion and that considered by the NRC in this paper. Mubayi's translation explicitly includes present worth considerations whereas in the NRC's formulation presented herein, the dollar per person-rem value appears on an undiscounted basis. However, when used in any particular regulatory application, NRC value impact guidance would require it, too, to be subject to present worth considerations. The difference is largely perceived as procedural although in comparing the staff's and Mubayi's dollar per person-rem results, the staff's estimate appears to be significantly larger than Mubayi's result.

Readers interested in a more detailed understanding of the data and issues underlying this report are encouraged to review the Mubayi and Baum reports. The Baum and Mubayi reports have been published as NUREG/CR-6212, and as NUREG/CR-6349.

\section{SCOPE OF DOLLAR PER PERSON-REM VALUE}

The NRC acknowledges that the dollar conversion factor of a person-rem is a highly complex issue and that a myriad of factors can logically be taken into account in deriving such a value. The NRC also recognizes that there is a wide divergence in views, some of which are highly philosophical in nature, and thus there is unlikely to be one clearly preferable choice that will please all interested parties. Furthermore, the NRC recognizes that simplicity, ease of calculation, and providing a readily understandable approach with practical application to a wide range of regulatory issues is desirable if the dollar per person-rem value is to be effectively employed. Overall, the NRC believes that a reasonable or representative value approach is best suited for NRC regulatory decisionmaking. The NRC emphasizes that such a value serves as only one input to the decisionmaker and in fact is unlikely to be a sole determinant to that decision. The most common application of dollar per person-rem conversion values is as a screening tool in value-impact analyses where "close" calls would be subject to more detailed follow-up analysis, and more careful scrutiny by NRC management.

In terms of scope, and specifically whether the dollar per person-rem value should cover both health effects and all other offsite consequences ${ }^{15}$ of exposure or contamination, the NRC proposes that the dollar per person-rem value serve only as a dollar proxy for the health effects associated with a person-rem of dose, and should not be used as a surrogate for these other consequences that could be attributable to radiological exposure. To the extent other considerations exist, these should be calculated separately and incorporated into the overall value-impact assessment.

Thus, for example, under this approach, for issues involving severe power reactor accidents, offsite property consequences will be estimated based on results from the MELCOR Accident

Consequence Code System (MACCS). This computer code was developed for the NRC at the Sandia National Laboratories and represents a significant advancement in the development of severe accident analysis methods, and results in improved offsite economic cost estimates relative to earlier consequence code results (CRAC and CRAC2). MACCS' economic parameters are in the process of being updated. When completed,

\footnotetext{
${ }^{15}$ Offsite consequences could include such items as lost wages, relocation expenses of the evacuated population, decontamination costs, denial of property areas, interdiction of foods or drink, and limitations on hunting and fishing.
} 
representative values for a spectrum of severe power reactor accidents will be developed and incorporated in NUREG/BR-0184, "Regulatory Analysis Technical Evaluation Handbook." For generic requirements, these estimates should provide an acceptable and relatively easy way to incorporate direct and explicit consideration of offsite property consequences. As noted previously, this would be a departure from the current NRC practice where the dollar per person-rem value is assumed to include an allowance for offsite property losses.

Three fundamental considerations underly an approach that separately values the health and other consequences of radiological exposure:

(1) Offsite property consequences can vary dramatically depending on the nature, timing, location, and magnitude of the radiological release. For example, in the case of the Three Mile Island Unit 2 (TM1-2) accident in 1979, offsite property damage was almost nonexistent. ${ }^{16}$ Alternatively, if a Chernobyl-type release occurred in the United States and led to the same physical consequences as actually happened in the environs of Chernobyl, the offsite damage costs (not including health-related costs) would likely be in the billions of dollars. Thus, the dollar quantification needs to take into account the full spectrum of potential accidents.

(2) Combining health- and nonhealth-related consequences together would overstate the dollar valuation of radiation exposure in certain applications such as occupational doses, routine emissions, doses from contaminated sites, and nonpower reactor accidental releases where offsite property losses are not an expected outcome.

(3) The sole purpose of the dollar per person-rem value is to allow the values and the impacts from a change in radioactive exposure to be compared to other factors in commensurate units, that is, dollars. There is consequently no need to include other impacts such as offsite property or the value of destroyed foodstuffs in the dollar per person-rem conversion factor since these items can be and are normally expressed directly in dollars. Similarly, to the extent that occupational

\footnotetext{
${ }^{16}$ U.S. Nuclear Regulatory Commission, Special Inquiry Group,

"Three Mile Island, A Report to the Commissioners and the

Public," NUREG/CR-1250, Vol. II, Part 2.
}

exposures involve labor cost considerations, these impacts would be addressed as a separate additive element in the value-impact analysis. The intent, therefore, is to provide a representative dollar per person-rem threshold value, tied exclusively to health risks, that can be used in all NRC regulatory applications.

\section{APPROACHES TO VALUING THE HEALTH DETRIMENT}

In this proposed formulation, computation of the updated dollar per person-rem valuation requires consideration of (1) the dollar value of the health detriment and (2) a risk factor that establishes the nominal probability for stochastic health effects ${ }^{17}$ attributable to radiological exposure. The product of these two elements is the dollar per person-rem conversion factor.

With respect to the dollar value of the health detriment, the NRC has reviewed the literature on the value of a statistical life. As discussed previously, the literature is highly diverse and dollar estimates vary dramatically. Based on the various methodological approaches and individual case results reported in the two BNL studies, it is apparent that varying degrees of justification exist over a very wide range of values. A review of the more common and relevant approaches to valuation of a statistical life follows.

\subsection{Human Capital Method}

The value of a life saved has often been estimated using purely economic considerations. The simplest of these is the human capital approach in which health effects and life shortening are typically estimated in terms of lost production and a dollar allowance for medical care. The production loss, which is the dominant dollar consideration, is often calculated based on the expected lifetime earnings of the individual whose life is prematurely ended. For unidentifiable individuals in the general public, this calculation is sometimes based on per capita gross domestic product (GDP), or per capita income. This model

\footnotetext{
${ }^{17}$ Stochastic health effects, i.e., cancer and heredity disorders, result from cells being modified rather than killed as a result of a low dose of radiation. The probability of a cancer resulting from radiation increases with increments of dose, probably with no threshold. ICRP Publication 60, "1990 Recommendations of the International Commission on Radiological Protection," Vol. 21, No. 1-3, published for the ICRP by Pergamon Press, Oxford, U.K., p. 69, 1991.
} 
does not directly attribute a monetary burden to physical and psychological suffering.

According to Baum, per capita income in 1990 was about $\$ 50$ per calendar day. The average value of a statistical life saved can then be estimated from the average life-span shortening expected if the risk is not avoided. For radiation-induced cancers, this averages about 15 years, ${ }^{18}$ yielding a value of statistical life saved of about 15 yr x 365 day/yr $\times \$ 50 /$ day $=\$ 270,000$. Adding costs of medical treatment would increase this by about 20 percent, whereas discounting future earnings and costs using a representative discount rate would approximately halve the value of a statistical life on a present worth basis.

Mubayi's report includes discussion of NRC-sponsored research conducted by the Pacific Northwest Laboratory (PNL). PNL developed the "Health Effects Cost Model" (HECOM), which utilizes the health effect incidence estimates from accident consequence models to calculate the discounted sum of the economic costs associated with population exposure to ionizing radiation. ${ }^{19}$ Direct costs include expenses for medical treatment for specific acute injuries, and delayed somatic and genetic effects. Indirect costs are evaluated in terms of "loss of human capital" (i.e., the productivity loss to society as a result of illness and premature death). Productivity loss is measured in terms of wages, modified to include nonwage-earning labor (household services). HECOM does not directly attribute a monetary burden to physical and psychological suffering.

Estimates of the value of avoided dose were made by Mubayi using the HECOM model.

Calculations were based on 20- and 30-year old male and female populations, and future medical costs and the loss of future earnings were subject to present worth considerations based on 3 percent and 7 percent real discount rates. Mubayi's results were updated to 1990 dollars using the inflation data from the medical costs and consumer price indices over this period. Based on Mubayi's adjustments to the HECOM model, exclusive of any adjustments to account for

\footnotetext{
${ }^{18}$ ICRP, op. cit., p. 134.

${ }^{19}$ L. A. Nieves and J. J. Tawil, "The Economic Costs of Radiation-Induced Health Effects: Estimated and Simulation," NUREG/CR-4811:PNL-6097, Pacific Northwest Laboratory, August 1988.
}

pain and suffering, a best-estimate for the value of a statistical life is on the order of about $\$ 500,000$.

The human capital approach reduces the value of human life to only economic considerations, and as such, has many recognized shortcomings. ${ }^{20}$ This approach typically ignores pain and suffering, lost enjoyment of life, and the value to family and community that is not reflected in GDP. It also has an implicit assumption that nonproductive individuals, (e.g., retired, unemployed) have minimal value. A report prepared for the Administrative Conference of the United States concluded that by 1988, use of the human capital method to value a statistical life in regulatory situations had lost whatever adherents it formally had. ${ }^{21}$

Interestingly, note that in 1993, the Health Physics Society issued a policy statement that linked the dollar valuation of a person-rem to the portion of gross domestic product currently being spent on extending life expectancy. 22 Computationally, this valuation is very similar to the human capital approach although its intention is not to assign a value to human life, but rather to optimize the use of limited resources for improving life expectancy and health benefits, when all risks are considered. This approach produces recommended values ranging from $\$ 40$ to $\$ 200$ per person-rem.

\subsection{Willingness-to-Pay Method}

The value society (i.e., an average person) places on improving safety is frequently based on the "willingness-to-pay" (WTP) approach. In theory, if there were a market for "buying" safety, then this approach would yield the price that the average "consumer" would be willing to pay to reduce the probability of death or what they would accept to have that probability increased. By using such an approach, the valuation of risk reduction is believed to reflect societal preferences and when applied in a cost-benefit framework will, in theory, reflect correct public allocation decisions. Quantification can, however,

\footnotetext{
${ }^{20} \mathrm{~A}$. Bequele, "The Cost and Benefits of Protecting and Saving Lives at Work: Some Issues." Intemational Labour Review, Vol. 123, No. 1, January-February 1984.

${ }^{21}$ C. P. Gilette and T. D. Hopkins, Federal Agency Valuations of Human Life," p. 53, July 1988.

${ }^{22}$ Health Physics Society, "Position Satement on Radiation Dose Limits for the General Public, Part II," March 1993.
} 
be very difficult and the method is criticized because of the large uncertainties in derived values. Nevertheless, many believe that such an approach is preferred to alternatives for estimating the value of a statistical life, particularly the human capital approach. The WTP approach is recommended by the Office of Management and Budget (OMB) as the preferred methodology for monetizing changes in the risk of fatalities. ${ }^{23}$ In addition, Recommendation No. 88-7 of the Administrative Conference of the United States states that "WTP provides the most inclusive analysis currently available for evaluating the benefits derived from regulatory reduction of fatalities."

WTP studies related to valuing a statistical life can be grouped into three categories: consumer market studies, wage-risk studies, and contingent valuation studies. ${ }^{24}$

The first category of WTP studies involves society's WTP based on actual consumer market studies. Such studies typically examine the tradeoffs between risk and benefits that people make in their consumptive decisions (e.g., seat belts, medical diagnostic tests, etc.). Based on their cost and probability of saving life, the cost of saving a life could be viewed as a proxy for the value of a life saved. In reality, however, many of these safety features reflect highly cost-effective ways to save lives and may understate what society is willing to spend to avert death. As a result, although such estimates provide an interesting and important perspective (i.e., what society is spending to save life), the upper end values of $\$ 2.2$ to $\$ 3.4$ million from Baum's consumer market review appear to more appropriately reflect the value of an averted death. This is because the dollar conversion factor of concern to the NRC is a threshold value that reflects how much society is or would be willing to spend to avoid a statistical death. The fact that, for certain risks, life can be saved

\footnotetext{
${ }^{23}$ Office of Management and Budget, "Regulatory Impact Analysis Guidance," Appendix V, p. 634, in "Regulatory Program of the United States Government: April 1, 1992 - March 31, 1993," Document No. S/N 041-001-00388-6, U.S. Government Printing Office, Washington, DC.

${ }^{24}$ A Fisher, L. G. Chestnut, and D. M. Violette, "The Value of Reducing Risks of Death: A Note of New Evidence," Journal of Policy Analysis and Management, Vol. 8, No. 1, pp 89, 1989.
}

relatively inexpensively should have little bearing on this consideration.

A second WTP approach involves wage-risk compensation. This is one of the most thoroughly studied approaches and presumes that the value that workers place on their lives is measurable based on observed wage differentials in occupations of varying risks. An advantage of this approach is that quantification is relatively easy because it is based on situations where real markets actually exist. Limitations of the wage-risk approach include workers (1) that may not know the extent of risk in particular occupations; (2) that may not be able to change occupations freely where risks are of concern; and (3) that may not incorporate the pain and suffering of friends and relatives, some of whom may be economically dependent on the worker, in their decisionmaking. Further it has been argued that, in many instances, wages and job-related fatalities seem to be inversely related since low-wage occupations tend to have a higher fatality rate than high-wage occupations. The Baum report identifies over 30 individual wage risk studies. For many of these studies, adjustments were made to try and make the studies as comparable and consistent as possible. On this basis, Baum reports value of statistical life estimates in 1990 dollars in a relatively narrow range ( $\$ 1.2$ million to $\$ 3.7$ million) and a median value of $\$ 2.5$ million.

The third WTP approach, contingent valuation studies, involves survey techniques to elicit responses to questions that postulate hypothetical market choices. The respondents are presented factual information, often during a personal interview. This information includes a detailed description of the goods being valued and the circumstances under which they are being made available. Respondents are queried on the price they would be willing to pay for the goods, as well as the respondent's own personal characteristics (e.g., age and income). The questions are carefully designed to minimize bias, and various techniques are used to randomize the sample and eliminate "poor" quality data. Although in theory this approach should most closely define society's price for buying safety, it is also the most difficult to quantify. Moreover, the public's perception of risk is not always consistent with the results obtained from analytical studies. Also, the means or approaches to measure the public's perceptions 
are often open to a variety of interpretations, resulting in answers that are inconsistent or inappropriate because of differing and undefined assumptions. Given these considerátions and limitations, Baum reports value of statistical life estimates in 1990 dollars ranging from a low of $\$ 0.1$ million to a high of $\$ 15.6$ million, with a median value of $\$ 3.1$ million.

\subsection{Values Implied by Government Agency Expenditures}

The Baum report summarizes studies where the value of saving a statistical life can be implied by the expenditures of Government agencies in the United States. Baum groups these studies into expenditures on health care, traffic safety, and programs to reduce radiation exposure. The studies imply values of saving a statistical life over a wide dollar range: all amounts are in 1990 dollars.

The health care expenditures data imply a value of a statistical life ranging from $\$ 12,000$ for scoliosis and neuromuscular disease to $\$ 2.6$ million for kidney dialysis. The traffic safety data imply values ranging from $\$ 85,000$ for regulatory and warning signs to $\$ 710,000$ for clearing roadside recovery areas. Implied values from government expenditures to reduce radiation exposure range as high as $\$ 490$ million to reduce exposure in the defense high-level radioactive waste program. The comparable figure for the civilian radioactive waste program is $\$ 44$ million.

\subsection{Values Implied by Regulatory Requirements Imposed by Government Agencies}

Baum also includes a number of examples in his report where a value of a statistical life can be inferred from the costs associated with implementing safety-related regulations. His report reviews data published by Travis, et al. ${ }^{25}$ on the costs and risk reduction of 11 regulations issued by Federal agencies involving chemical carcinogenic products. Values (in 1990 dollars) per fatal-cancer avoided range from $\$ 0.04$ million for chromium to $\$ 25$ million for chlorobenzilate. The median value is $\$ 2.9$ million (Baum, Table 8 ).

\footnotetext{
${ }^{25}$ C. C. Travis, S. R. Pack, and A. Fisher, "Cost-Effectiveness as a Factor in Cancer Risk Management," Environmental International, Vol. 13, pp. 469-474, 1987.
}

Travis, et al. concluded that when lifetime cancer risk exceeds about $4 \times 10^{-3}$, chemicals were regulated regardless of cost. Alternatively, if the lifetime risk ranged from $10^{-6}$ to $4 \times 10^{-3}$, regulations were only implemented if the value of a statistical life was less than $\$ 2$ million. Thus, the relevance of relatively high dollar estimates of the value of a statistical life derived from previous regulatory decisions is uncertain or unclear, since it is most likely that in these instances the decision was not based on a cost-benefit analysis but rather was based solely on the unacceptability of the risk.

Baum cites examples of other regulatory actions taken by the Department of Transportation (DOT), the Environmental Protection Agency (EPA), the Occupational Safety and Health Administration (OSHA), and the Consumer Product Safety Commission (CPSC) where the implied value of a statistical life in 1990 dollars ranges from $\$ 130,000$ to $\$ 91$ billion. Recent work by Van Houtven and Cropper suggests that the implied value of a statistical life used by EPA in regulating asbestos under the Toxic Substances Control Act and pesticides under the Federal Insecticide, Fungicide, and Rodenticide Act falls between $\$ 49$ and $\$ 52$ million (measured in 1989 dollars). ${ }^{26}$ OMB has compiled a list of a large number of Federal agency actions where the cost of a premature death averted (in 1990 dollars) as a result of an agency's regulatory actions ranges from $\$ .1$ to $\$ 5,700,000$ million. 27

\subsection{Values Based on Radiation Protection Activities in Other Countries}

Baum's review included contacting other countries to obtain information on their cost-benefit guidance in dealing with radiation protection issues. In the United Kingdom (UK), the National Radiological Protection Board (NRPB) has considered both the human capital and WTP approaches in estimating an appropriate value of a statistical life. Up until about 1990, the NRPB resisted using values based on WTP because of, in their view, the paucity of reliable WTP data. Recently, the NRPB has cited with approval a recommendation for a value of statistical life in the range of about $\$ 3$ million to $\$ 4.5$ million, and

\footnotetext{
${ }^{26}$ G. L. Van Houtven and M. L. Cropper, "When is a Life Too Costly to Save? The Evidence from Environmental Regulations," Resources, Resources for the Future, p. 6, Winter 1994.

${ }^{27} \mathrm{OMB}$, op. cit., p. 28.
} 
a study ${ }^{28}$ indicating a value of statistical life on the order of $\$ 2.4$ million in 1990 dollars.

It is interesting to note that the UK also looked at the value of statistical life in dealing with transportation safety issues. In 1988, a report sponsored by the UK Department of Transport proposed that the then current reliance on the human capital approach be abandoned in favor of the WTP approach and that the value of life be set at about $\$ 1.0$ million (in 1990 U.S. dollars). In 1989, the UK sponsored a WTP survey involving over 1000 respondents and professional interviewers. This study concluded that residents in the UK were prepared to spend $\$ 3.2$ million for certain highway improvements to save a life.

\subsection{Representative Value of a Statistical Life}

As noted earlier, the variation in the value of statistical life as estimated and used for a number of applications is tremendously broad (less than $\$ 100,000$ to billions of dollars). However, when viewed critically, it appears that median values for a realistic value of a statistical life tend to range from a low of about $\$ 1.3$ million to a high slightly over $\$ 3$ million. Both higher and lower estimates were identified and evaluated; however, higher estimates seem to result from decisions based primarily on motivations other than the WTP concept, and lower estimates seem to reflect more the cost of saving a life rather than the value of life. The NRC also chose to dismiss the human capital approach for estimating the value of a statistical life because it understates value by only addressing one aspect of human life.

The NRC contends that the dollar per person-rem conversion factor should be reasonable and representative, and thus should be consistent with the preponderance of the estimates. A value of a statistical life of $\$ 3$ million seems to best match these objectives. This value (1) is consistent with results from the WTP approach, which is recommended by $\mathrm{OMB}$ and the Administrative Conference of the United States, and is most favored in the literature; (2) reflects median values of a statistical life estimated in many studies; (3)

\footnotetext{
${ }^{28}$ D. Ives, D. Thieme, and R. Kemp, "The Statistical Value of Life and Safety Investment," Reseach Report No. 13, Environmental Risk Assessment Unit, Unversity of East Anglis, Norwich, UK, 1993.
}

is representative of values used by other Federal agencies responsible for public health and safety; (4) is in general agreement with values used for regulatory decisionmaking in other countries; and 5 ) is specifically cited by $\mathrm{OMB}$ as a "best estimate" for the value of a statistical life using the WTP approach. ${ }^{29}$

A representative value of a statistical life and not an upper bound is appropriate for several reasons. First, the value will influence national energy-related decisions, and realistic safety-cost tradeoffs help to ensure an equitable treatment of all energy sources or options. Second, a value that is in reasonable agreement with values used by other Federal agencies involved in health and safety will help ensure risk harmonization and that decisions throughout the Federal Government reflect an efficient and proper allocation of society's resources. Third, if too high a value is chosen, money that would otherwise be available to society to save lives would not be available, and a regulatory requirement could have the perverse effect of increasing overall mortality risk. ${ }^{30}$ Finally, a representative value is a useful guide in making decisions on "worthwhile" regulatory initiatives and reflects one reference point. NRC's regulatory decisions are ultimately based on numerous considerations of which the results of a regulatory analysis are but one input. Also, it bears repeating that the dollar value ultimately attached to averted dose will have no effect on actions deemed necessary by the NRC to ensure adequate protection to the health and safety of the public.

\section{RISK COEFFICIENTS FOR STOCHASTIC HEALTH EFFECTS}

Once an appropriate value of statistical life has been estimated, the parameter needed to convert that value to a dollar per person-rem figure is the risk coefficient that establishes the nominal probability for stochastic health effects attributable to radiological exposure. The national and international bodies (NCRP, ICRP) responsible for evaluating and recommending

\footnotetext{
${ }^{29} \mathrm{OMB}$, op. cit., p. 27.

${ }^{30} \mathrm{OMB}$, op, cit., This concept, referred to by $\mathrm{OMB}$ as

"health-health analysis," is discussed at pages 19-30 of OMB,

"Regulatory Program of the United States Government"

document.
} 
such a value are in close agreement. The NRC proposes to use the latest recommendations of the ICRP as presented in their Publication No. 60. In general, for doses to the general population, their recommendation is a risk coefficient of $7.3 \times 10^{-4}$ per rem. ${ }^{31}$ This coefficient accounts for the probability of occurrence of a harmful health effect and a judgement of the severity of the effect. The coefficient includes allowances for fatal and nonfatal cancers and for severe hereditary effects. The nonfatal cancers and hereditary effects are translated into loss-of-life measures based on a perceived relationship between quality of life and loss of life. In this way, the value of statistical life is applicable across all contributors to the total health risk coefficient. For NRC regulatory applications, it is proposed that the risk coefficient be reduced to one significant digit to better reflect the level of accuracy inherent in its derivation. The risk coefficient of $7.0 \times 10^{-4}$ per person-rem can than be used with the value of a statistical life to derive a dollar conversion factor per person-rem. Using the risk coefficient in this manner has the effect of attributing proportional risks to very small doses even though there is no convincing evidence of proportional risks at background levels. However, in the absence of such evidence, scientific organizations such as ICRP and NCRP have concluded that it is prudent to assume a linear relationship for the purpose of planning and implementing radiation protection programs.

\section{DOLLAR PER PERSON-REM CONVERSION FACTOR}

The dollar per person-rem conversion factor for health effects can now be calculated as the product of the value of a statistical life and the risk coefficient. Based on the preceding recommendations concerning the value of a statistical life ( $\$ 3$ million) and the risk coefficient for stochastic health effects $\left(7.0 \times 10^{-4}\right)$, the dollar conversion factor for health effects would equal $\$ 2100$ per person-rem. Given the large uncertainties already inherent in this approach, it would appear reasonable to adopt a dollar conversion factor rounded to the nearest thousand dollars. Thus, the NRC proposes that $\$ 2000$ per person-rem be used for routine emissions,

\footnotetext{
${ }^{31}$ ICRP, op. cit., p. 70.
}

accidental releases, and 10 CFR Part 20 ALARA programs (i.e., occupational exposures). Pertaining to occupational exposures, the NRC acknowledges that, for ALARA determinations, many licensees employ conversion factors in excess of $\$ 2000$ per person-rem. This is particularly true in nondesign ALARA determinations where licensees consider trade offs between occupational dose and alternative technologies and procedures (e.g., additional shielding, remote or robotic tools). These higher values are typically influenced by utility-specific manpower constraints and other labor cost considerations. These are valid utility considerations in evaluating occupational exposures, and licensees are expected to continue to use these higher conversion factors. Further, such values are not necessarily inconsistent with the NRC's $\$ 2000$ value that only captures health effects, as other impacts such as labor cost considerations can be treated as additive elements in the NRC's value-impact analysis.

The NRC acknowledges that there may be unique circumstances where other dollar conversion factors may warrant consideration. For example, doses to a population whose age distribution is not representative of the general population could be subject to a different risk coefficient because health risks are directly related to the age distribution of the affected population. Further, recognizing the uncertainties inherent in establishing a representative conversion factor, alternative values to capture the uncertainties may be warranted. Thus, it would be reasonable to expect an analyst to include alternative valuations in regulatory analyses in order to show the decision maker the sensitivities of the proposed action to relevant considerations. However, the base case computations in a regulatory analysis will normally use the recommended dollar conversion factor of $\$ 2000$ per person-rem.

The dollar per person-rem conversion factor is for stochastic effects only and is not to be applied to deterministic effects. ${ }^{32}$ It should also not be applied to any individual dose that could result in an early fatality. These omissions are consistent with NRC's view that the monetizing of mortality

\footnotetext{
${ }^{32}$ Deterministic health effects in humans can result from general or localized tissue irradiation causing an amount of cell killing that cannot be compensated for by the proliferation of viable cells. The resulting loss of cells can cause severe and clinically detectable impairment of function in a tissue or organ. ICRP, op. cit., p. 99.
} 
effects as it relates to the value of any single individual's life is not appropriate. Rather, its use is as an estimate of the value of small reductions in the probability of death for a given population. From a practical perspective, the NRC believes that regulatory issues involving deterministic effects and or early fatalities would be very rare, and can be addressed on a case-specific basis, as the need arises.

\section{IMPLICATIONS OF REVISED CONVERSION FACTOR POLICY}

The $\$ 2000$ per person-rem conversion factor discussed in this report reflects a two-fold increase from the $\$ 1000$ per person-rem conversion factor that has historically been used by the NRC. However, as discussed in Revision 2 of the NRC's Regulatory Analysis Guidelines, any increase in the dollar value of health effects will now be subject to present worth considerations that will decrease the apparent effect of a new, higher dollar per person-rem conversion factor.

For most regulatory applications, the net effect of these two changes is a wash. For example, the total dollar value of averting one person-rem per year over a 20 -year timeframe is $\$ 20,000$ based on an undiscounted $\$ 1000$ conversion factor policy. Applying a $\$ 2000$ conversion factor and assuming the Guidelines recommendation of a 7-percent real discount rate results in a total dollar value of $\$ 21,200$.

Another change in NRC's conversion factor policy involves separate quantification of offsite property consequences. The NRC recognizes that separate quantification of offsite property will have limited application in regulatory decision making. This is because offsite property consequences are not an expected outcome for most radiological releases. This is true for occupational doses, routine emissions, doses from contaminated sites, and most accidental releases from nonpower reactors. However, in those regulatory applications involving severe power reactor accident scenarios, the difference in total dollar value could be important. For example, applying the same assumptions just stated, but this time including a $\$ 3000$ per person-rem allowance for offsite property consequences, the total dollar value of averting one person-rem per year over 20 years would increase from $\$ 20,000$ to $\$ 53,000$, an increase of about a factor of 2.5. Further, under unique circumstances the differential could be far more significant. For example, consider a proposed regulatory requirement that reduces the probability of severe power reactor accidents in which there is typically a long delay in offsite release. Since interdiction measures can be very effective in such cases, the public health and safety benefit based solely on person-rem averted would be very small. This however, would completely omit the large offsite property consequences associated with the interdiction effort.

As part of the NRC's overall reassessment of an appropriate dollar per person-rem conversion factor, the NRC considered the potential impact of any change in the $\$ 1000$ per person-rem factor on current regulations and past regulatory decisions. In the introductory sections of this report, the NRC attempted to characterize the role that the $\$ 1000$ per person-rem played, and is expected to exert in future NRC regulatory decisions. First, with regard to regulatory decisions concerning radwaste system design alternatives for nuclear power plants (10 CFR Part 50, Appendix I), the NRC staff involved in those assessments have indicated that increases in the conversion factor of at least an order of magnitude would be necessary to justify any reassessment of these decisions. Thus, the changes in the conversion factor policy as considered in this report would not bring into question these past decisions. Second, for all other regulatory applications where $\$ 1000$ per person-rem has been used by the NRC, the NRC is not proposing that previous decisions be reviewed or updated based on this revised conversion factor policy because in most regulatory applications the difference in total dollar valuation is minimal between these two options. Furthermore, even for regulatory decisions involving safety enhancements for severe power reactor accidents where the potential difference in total dollar valuation could be large, the NRC does not propose revisiting these past regulatory decisions unless, on a case-specific basis, an unanticipated need to do so arises. There are several reasons for this position. First, the $\$ 1000$ per person-rem value has been used by the NRC as a figure of merit, and as one input among many in the regulatory decision. Second, 
in recognition of the uncertainties inherent in such a figure of merit, NRC staff and decisionmakers would typically rely more heavily on other considerations when the break-even conversion factor was close (within a factor of 5) to the $\$ 1000$ per person-rem guide. Finally, it is very likely that the cost of making an improvement to a licensed facility to reduce the probability of radiation exposure has increased commensurately with the increase in dollar valuation that would result from the changes in conversion factor policy under consideration in this report.

\section{PROCESS TO INCORPORATE THE REVISED DOLLAR PER PERSON-REM VALUE AS NRC POLICY}

The $\$ 2000$ per person-rem conversion factor and related changes in NRC's conversion factor policy have been incorporated in "Regulatory Analysis Guidelines of the U.S. Nuclear Regulatory Commission," NUREG/BR-0058, Revision 2, November 1995. In addition, the NRC intends to provide more detailed guidance on implementing this policy in NRC's "Regulatory Analysis Technical Evaluation Handbook" (Handbook), which is scheduled to be published in 1996.

The deletion of all references to the present $\$ 1000$ per person-rem value in existing regulations and guidance will be considered. The only reference in the Code of Federal Regulations to the $\$ 1000$ per person-rem value is in 10 CFR Part 50,
Appendix I (Sec.II)(D) that concerns routine emissions for radwaste system designs at power reactors. Regulatory Guide 1.109 contains guidance on performing dose calculations and the use of $\$ 1000$ per person-rem for the dollar valuation for radwaste system design alternatives for power reactors. Also, Regulatory Guide 8.37 suggests the use of $\$ 1000$ per person-rem in determining ALARA levels for radiological effluent from materials facilities. NUREG-0933, "A Prioritization of Generic Safety Issues" utilizes $\$ 1000$ per person-rem in assigning priorities and resolving generic safety issues. In other regulatory applications [e.g., regulatory analyses, backfit -analyses, SAMDA analyses, and analyses in response to 10 CFR 50.34(f)(1)(i)], the NRC currently draws upon the 1983 "Handbook for Value-Impact Assessment" as the basis for its valuation of radiological dose and will correspondingly draw upon the revised Handbook when it is issued in final form.

The NRC recognizes that updating the dollar per person-rem conversion factor may be appropriate in the future. Consequently, the NRC intends that the dollar per person-rem conversion factor be subject to periodic review. The dollar per person-rem conversion factor would only be adjusted if changes in the underlying parameters cause the base conversion factor (when rounded to the nearest thousand dollars) to shift up or down by a thousand dollars or more. The NRC's update will consider such factors as changes in the value of the dollar, new research addressing the appropriate value of a statistical life in governmental decisionmaking, or a change in recommended radiation risk coefficients. 


$\begin{array}{lc}\text { NRC FORM } 335 & \text { U.S. NUCLEAR REGULATORY COMMISSION } \\ (2-89) & \\ \text { NRCM 1102, } & \\ 3201,3202 & \text { BIBLIOGRAPHIC DATA SHEET } \\ & \text { (See instructions on the reverse) }\end{array}$

2. TITLE AND SUBTITLE

Reassessment of NRC's Dollar Per Person-Rem Conversion Factor Policy
1. REPORT NUMBER

(Assigned by NRC, Add Vol. Supp., Rev., and Addendum 'Numbers, if any.)

NUREG-1530

3. DATE REPORT PUBLISHED

MONTH

December

YEAR

1995

4. FIN OR GRANT NUMBER

6. TYPE OF REPORT

Technical

7. PERIOD COVERED (Inclusive Dates)

8. PERFORMING ORGANIZATION - NAME AND ADDRESS (If NRC, provide Division, Office or Region, U.S. Nuclear Regulatory Commission, and mailing address; if contractor, provide name and mailing address.)

Division of Regulatory Applications

Office of Nuclear Regulatory Research

U.S. Nuclear Regulatory Commission

Washington, DC 20555-0001

9. SPONSORING ORGANIZATION - NAME AND ADDRESS (If NRC, type "Same as above"; if contractor, provide NRC Division, Office or Region, U.S. Nuclear Regulatory Commission, and mailing address.)

Same as item \#8

10. SUPPLEMENTARY NOTES

11. ABSTRACT (200 words or less)

The U.S. Nuclear Regulatory Commission (NRC) has completed a review and analysis of its dollar per person-rem conversion factor policy. As a result of this review, the NRC has decided to adopt a $\$ 2000$ per person-rem conversion factor, subject it to present worth considerations, and limit its scope solely to health effects. This is in contrast to the previous policy and staff practice of using an undiscounted $\$ 1000$ per person-rem conversion factor that served as a surrogate for all offsite consequences (health and offsite property). The policy shift has been incorporated in "Regulatory Analysis Guidelines of the U.S. Nuclear Regulatory Commission," NUREG/BR-0058, Revision 2, November 1995.

12. KEY WORDS/DESCRIPTORS (List words or phrases that will assist researchers in locating the report.)

Value-Impact Analysis

Regulatory Analysis

Radiological Exposure

Dollar Per Person-rem Conversion Factor

Value of Statistical Life

Health and Safety Benefit
13. AVAILABIUTY STATEMENT Unlimited

14. SECURITY CLASSIFICATION

(This Page)

Unclassified

(This Report)

Unclassified

15. NUMBER OF PAGES

16. PRICE 